\title{
CHARACTERIZING AND MODELING COMBUSTION OF MILD-GASIFICATION CHARS IN PRESSURIZED FLUIDIZED BEDS
}

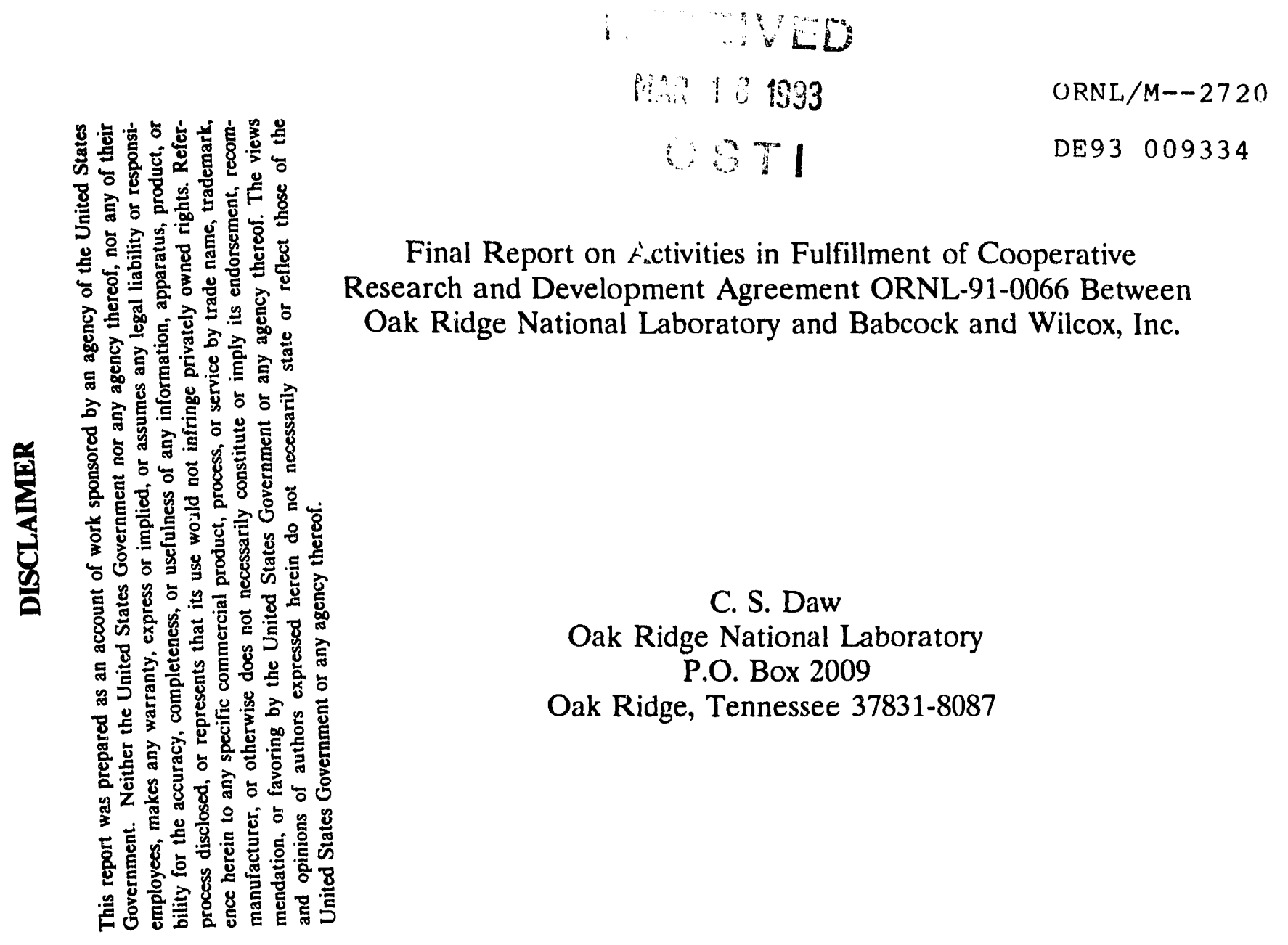

The submitted manuscript has been authored by a contractor of the U.S. Government under contract No. DE-ACO5-84OR21400.
Accordingly, the U.S. Government retains a nonexclusive, royalty-free license to publish or reproduce the published form of this contribution, or allow others to do so, for U.S. Government purposes."

*Research sponsored by the U.S. Department of Energy, Fossil Energy Program unier c01. act DE-AC05-84OR21400 with Martin Marietta Energy Systems, Inc. 


\section{INTRODUCTION}

Oak Ridge National Laboratory (ORNL) is supported by the Morgantown Energy Technology Center (METC) of the Department of Energy (DOE) under FWP-FEAA310 to characterize the fuel properties of liquid and char coproducts from the mild gasification of coal. Because most of the energy content of coals subjected to mild gasification is retained in the byproduct char, efficient and cost-effective utilization of the char is essential in ensuring that candidate gasification processes are commercially viable.

One potential use for char of particular interest to DOE is pressurized fluidized bed combustion (PFBC). PFBC is of particular interest because it has the potential for 10 to $30 \%$ greater overall energy efficiency than atmospheric fluidized bed combustion (AFBC). While bench-scale tools and analytical procedures for characterizing fuels for AFBC have been recently' demonstrated $(1,2)$, no such tools have been reliably demonstrated for PFBC. Previous characterizations of mild-gasification chars as AFBC fuels have been conducted by ORNL and Babcock and Wilcox, Inc. $(B \& W)(3,4)$.

This report summarizes the results of joint research collaboration between ORNL and B\&W that has been directed at modifying the previously developed AFBC fuel characterization procedures to be applicable for mild-gasification chars and PFBC conditions. It has been carried out by both parties under a Cooperative Research and Development (CRADA) designated as ORNL-91-0066. The specific objectives were to: 1) characterize the combustion reactivity of a selected set of candidate mild-gasification chars at PFB conditions; 2) compare the measured char characteristics with those of more conventional PFBC fuels; 3) modify an AFBC computer code previously developed by B\&W and ORNL for the Electric Power Research Institute (EPRI) to predict PFBC performance; and 4) apply the modified code and measured char comtustion characteristics to make performance predictions for the candidate chars relative to more conventional fuels.

\section{CANDIDATE CHARS AND REFERENCE FUELS}

The chars selected for inclusion in this study were produced by candidate mild-gasification processes developed by four groups: 1) Coal Technology Corporation (CTC, formerly part of United Coal Company); 2) SGI International (which technology is now incorporated in the ENCOAL process); 3) the Institute of Gas Technology (IGT) and Peabody Coal Company; and 4) Western Research Institute (WRI) and AMAX Coal Company.

The CTC char sample (designated here and in previous reports as UCC2) was produced under typical operating conditions in the atmospheric, externally-heated, fixed-bed pilot unit at Bristol, Virginia (5). The parent coal was Kentucky Williamson No.2, a high-volatile, swelling bituminous type. The feed particles for this candidate process were typically $11 / 2$ in. top size, and the mild-gasification conditions were reportedly rather severe (e.g., temperatures up to $1200^{\circ} \mathrm{F}$ and several hours residence time). 
The SGI char sample was obtained by mild-gasification of Montana Rosebud subbituminous coal under relatively mild conditions [e.g., temperatures below $1200^{\circ} \mathrm{F}$ and residence times on the ordar of a few minutes (6)]. Typical coal feed top size appears to have been $1 / 4$ in. Details of the process conditions have not been made generally available for proprietary reasons. The specific SGI sample chosen was that designated as SGI20 in previous reports.

Two char samples from the IGT-Peabody process were included. The first (designated previously and here as IGTP1) was produced from Illinois No. 6 high-volatile bituminous coal. The second (designated previously and here as IGTP2) was produced from a West Virginia high-volatile, metallurgical bituminous coal. The process coal feed sizes were $70 \mathrm{wt} \%<840$ microns and $90 \mathrm{wt} \%<420$ microns, respectively. Typical conditions in the fluidized bed/entrained bed pilot reactor were 1100 to $1400^{\circ} \mathrm{F}$ at $<4.5$ atm with once-through solids residence times on the order of 10 minutes. Approximately 15 to $20 \%$ of the feed consists of recycled char which increases the overall effective residence time (7).

One char sample (designated here and previously as WRIA2) was obtained from the WRI/AMAX process from Wyodak Powder River Basin subbituminous coal. This particular char is not typical of the standard product coming from the inclined fluidized bed reactor but instead represents a severely posttreated material from an AMAX proprietary process. The average size of the original feed was approximately 500 microns. Typical conditions in the inclined fluidized bed reactor are $1160^{\circ} \mathrm{F}$ maximum at atmospheric pressure with a solid residence time of about 5 minutes.

Four well-known reference coals were included in the combustion testing and PFBC performance simulations to act as benchmarks for the mild-gasification chars. These fuels were Beulah lignite, Pittsburgh No. 8 high-volatile bituminous, Illinois No. 6 high-

volatile bituminous, and anthracite. Table 1 summarizes the ultimate and proximate analyses of the test chars, their parent coals, and the reference coals.

\section{BENCH-SCALE COMBUSTION CHARACTERIZATION TESTS}

A bench-scale, pressurized, fixed-bed reactor was used to characterize the time-resolved combustion behavior of the char samples. The reactor, developed by B\&W and located at the $\mathrm{B} \& \mathrm{~W}$ Alliance Research Center, is designed to simulate the temperatures, pressures, and oxygen concentrations of typical PFBC conditions (8). It has been designed to be similar to the bench-scale atmospheric fixed-bed reactor developed for EPRI $(1,2)$, except that it operates under pressure. Figures $1 \mathrm{a}$ and $\mathrm{b}$ are overall and closeup schematics of the pressurized reactor, respectively.

During typical operation, a weighed and sized solid fuel sample (in this case the char or reference coal samples) are injected nearly instantaneously into the top of the reactor via a lock-hopper system. The sample lands on top of a bed of particulate solids somposed of spent fluidized bed sorbent. Preheated gas of controlled composition (typically oxygen and 
Table 1. Ultimate and proximate analyses of the test chars, parent coals, and reference fuels. All analyses are as weight percent on an as-received basis. Hydrogen values reported include $\mathrm{H}$ from water.

\begin{tabular}{|l|r|r|r|r|r|r|r|r||}
\hline & \multicolumn{4}{|c|}{ Ultimate } & \multicolumn{5}{|c|}{ Proximate } \\
\cline { 2 - 8 } & \multicolumn{1}{|c|}{$\mathrm{C}$} & \multicolumn{1}{c|}{$\mathrm{H}$} & $\mathrm{N}$ & $\mathrm{S}$ & \multicolumn{1}{c|}{ Ash } & Water & $\mathrm{VM}$ & $\mathrm{FC}$ \\
\hline Chars: & & & & & & & & \\
UCC2 & 83.9 & 3.2 & 1.5 & 0.7 & 5.9 & 2.3 & 11.5 & 80.3 \\
SGI20 & 68.3 & 2.3 & 1.1 & 1.0 & 15.6 & 6.8 & 14.0 & 63.5 \\
WRIA2 & 86.8 & 0.6 & 0.5 & 0.3 & 8.5 & 3.7 & 4.1 & 83.6 \\
IGTP1 & 73.8 & 1.0 & 1.0 & 2.0 & 19.1 & 2.4 & 9.5 & 69.1 \\
IGTP2 & 83.2 & 2.7 & 1.3 & 1.4 & 8.6 & 1.6 & 7.6 & 82.3 \\
\hline Parent coals: & & & & & & & & \\
KY WL.2 (CTC) & 78.2 & 5.2 & 1.5 & 1.0 & 5.0 & 1.8 & 1.8 & 59.4 \\
MT ROS. (SGI) & 54.8 & 3.7 & 0.8 & 0.6 & 9.2 & 19.8 & 19.8 & 51.8 \\
WYODAK (WRIA) & 52.8 & 3.1 & 0.6 & 0.3 & 4.7 & 25.5 & 25.5 & 37.3 \\
ILL. 6 (IGTP1) & 60.8 & 4.1 & 1.4 & 3.6 & 13.2 & 7.7 & 7.7 & 44.6 \\
W VA. (IGTP2) & 74.3 & 4.8 & 1.2 & 1.0 & 5.5 & 7.3 & 7.3 & 55.2 \\
\hline Ref. coals: & & & & & & & & \\
BH LIGNITE & 43.6 & 2.3 & 0.5 & 0.7 & 6.2 & 32.6 & 28.9 & 32.3 \\
PITT. 8 & 70.2 & 4.9 & 1.6 & 2.2 & 8.6 & 5.2 & 38.1 & 48.1 \\
ILLINOIS 6 & 63.6 & 4.0 & 1.3 & 3.1 & 9.7 & 8.9 & 36.6 & 44.8 \\
ANTHRACITE & 78.3 & 1.9 & 0.8 & 0.6 & 10.9 & 4.5 & 6.0 & 78.7 \\
\hline
\end{tabular}

nitrogen) enters at the top of the reactor chamber, flows down through the sample and bed, out of the bed into a heated post-combustion zone, and then through coolers and fast-response gas analyzers.

The gases evolved during devolatilization and combustion are analyzed for $\mathrm{CO}, \mathrm{CO}_{2}, \mathrm{O}_{2}$, and total hydrocarbons. The measurements of each of these components are recorded on a computer as concentration versus time. From these measurements, it is possible to distinguish both devolatilization and char combustion and to determine the relevant rate equation parameters for simulating devolatilization and combustion behavior. Details on the rationale for the reactor design and the interpretation of the measurements are given elsewhere $(1,2,8)$.

Over the last few years, B\&W has been developing a fuel parameter data base for both atmospheric and pressurized conditions. For the purposes of estimating the PFBC performance of the candidate mild-gasification chars, previous experience indicates that accurate determination of char combustion parameters rather than devolatilization parameters is of greater importance $(1,2)$. For that reason, the bench-scale fixed bed tests were designed to focus on measurement of the char combustion rate for each fuel under 


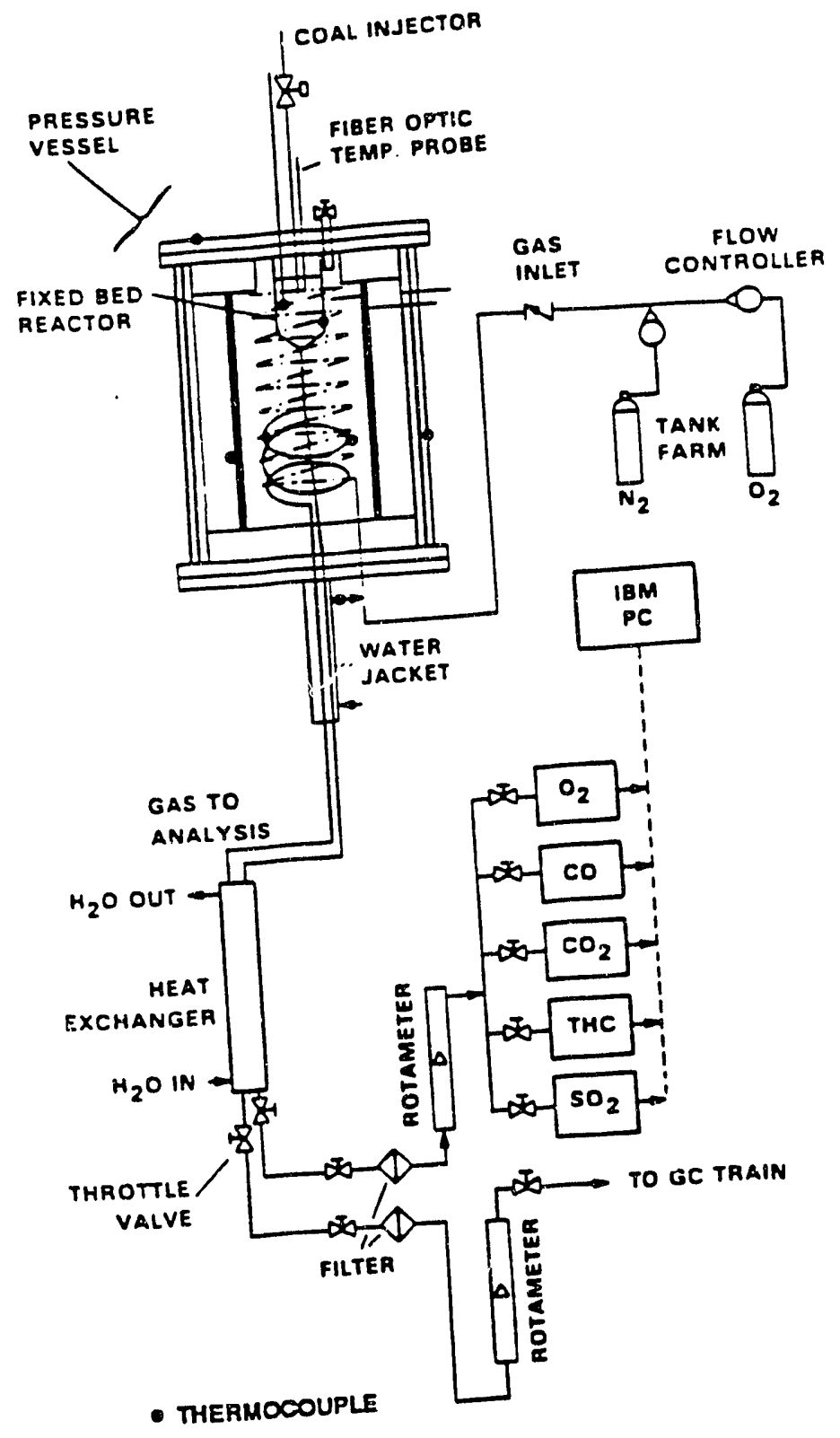

Fig. 1a. Overall schematic of the bench-scale pressurized fixed-bed reactor and auxiliary equipment. 


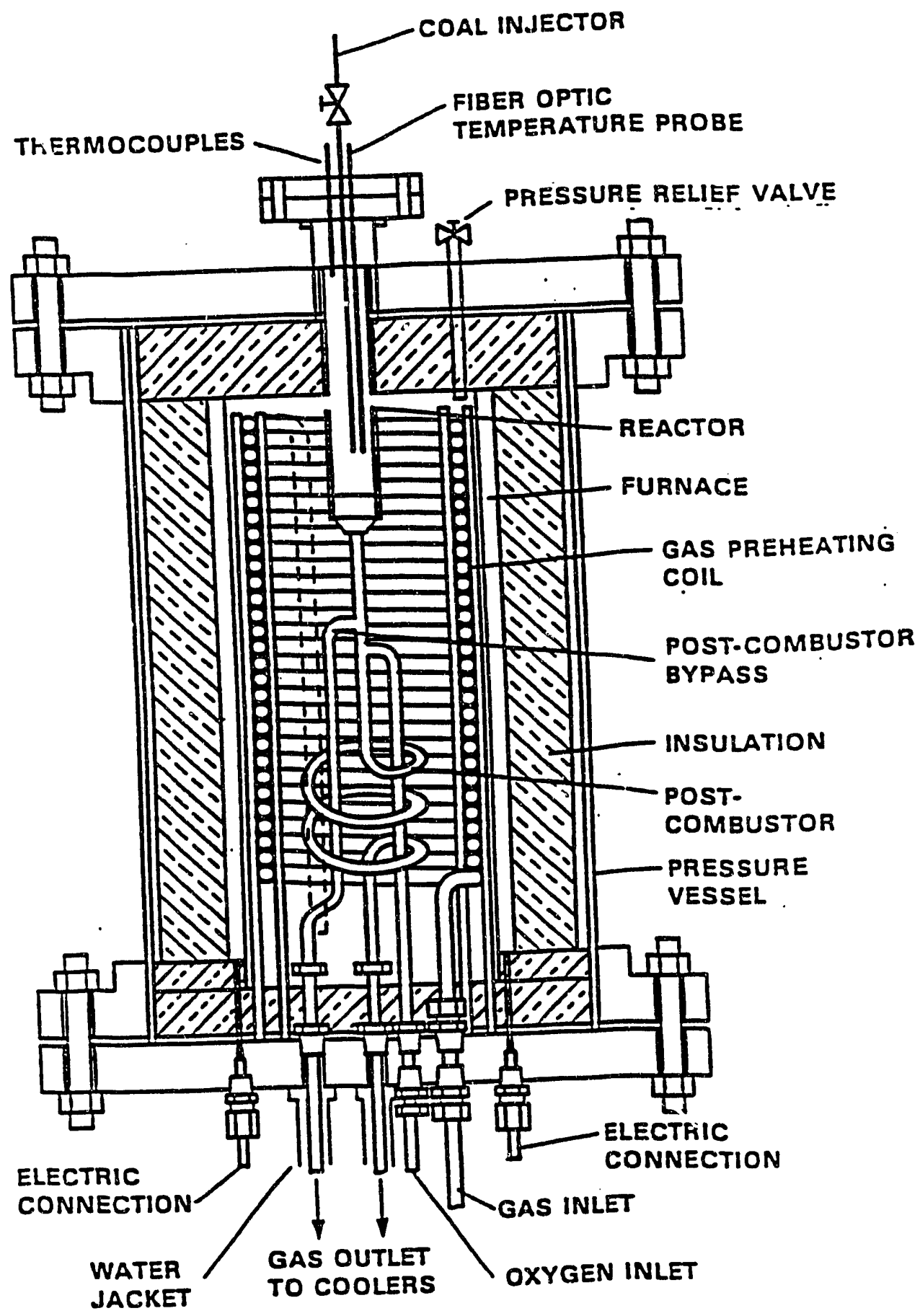

Fig. 1b. Detail of the pressurized fixed-bed reactor. 
conditions of varying pressure, temperature, and oxygen concentration. The nominal pressure, temperature, and oxygen concentration ranges were $10-15 \mathrm{~atm}, 1200-1600^{\circ} \mathrm{F}$, and 0.5 to $3 \%$ oxygen, respectively. All fuels tested were crushed and double-screened to give a nominal particle size of 115 microns. The latter size has been determined from experience to give results that are dominated by kinetics rather than gas-phase diffusion. Further corrections are also made for gas-phase diffusion effects and dispersion of the gas in the piping and analyzers through application of experimentally derived correlations $(1,2,9)$.

Test results revealed that the combustion rate constants for the UCC2, IGTP1, and IGTP2 chars could be accurately measured with the bench-scale reactor, but there was significant uncertainty in the results for the SGI and WRIA chars. The principal difficulty with the latter two was their high burning rate. Both of these chars, as well as many subbituminous and lignitic fuels, burn sufficiently rapidly that they exceed the resolution of the pressurized bench-scale system (which is not as good as that of the atmospheric bench-scale reactor developed previously). For this reason, no pressurized combustion characterization results are presented here for SGI20 and WRIA2. It is the opinion of the author that such fuels can not be accurately characterized by the $B \& W$ pressurized reactor until additional modifications are made to the equipment and analysis procedures.

Figures 2 through 4 summarize the combustion rate results for the UCC2, IGTP1, and IGTP2 chars. Note that the data point symbols indicate the pressure at which the rate measurements were made. These plots are in the standard Arrhenius format which is based on the assumption that carbon combustion rate can be expressed as

$$
\mathrm{d} \theta / \mathrm{dt}=-\mathrm{A} \exp \left(-\mathrm{E} / \mathrm{RT}_{\mathrm{p}}\right) \mathrm{C}_{\mathrm{O}}
$$

where $\boldsymbol{\theta}$ is the fraction of the original fixed carbon that remains at time $t, R$ is the ideal gas constant, $T_{p}$ is the particle temperature, and $C_{0}$ is the oxygen concentration at the particle surface. The parameters $\mathbf{A}$ and $\mathbf{E}$ are the Arrhenius rate parameters that are sometimes referred to as the pre-exponential factor and activation energy, respectively. The parameter $\mathbf{n}$ is the reaction order in oxygen.

Previous measurements at near atmospheric pressures has demonstrated that good "fits" of the observed burning rates can be obtained when $\mathbf{n} \approx 0.5$ and the oxygen partial pressure is used to represent oxygen concentration. Pressurized fixed-bed experience also indicates that this assumption is acceptable under higher pressures.

Figure 5 summarizes the "average" burning rates of UCC2, IGTP1, and IGTP2 versus temperature as determined from their estimated Arrhenius parameters. The average burning rates of the reference fuels are also included for comparison. Note that the line for Beulah lignite has been estimated based on measurements in the atmospheric bench-scale reactor. 


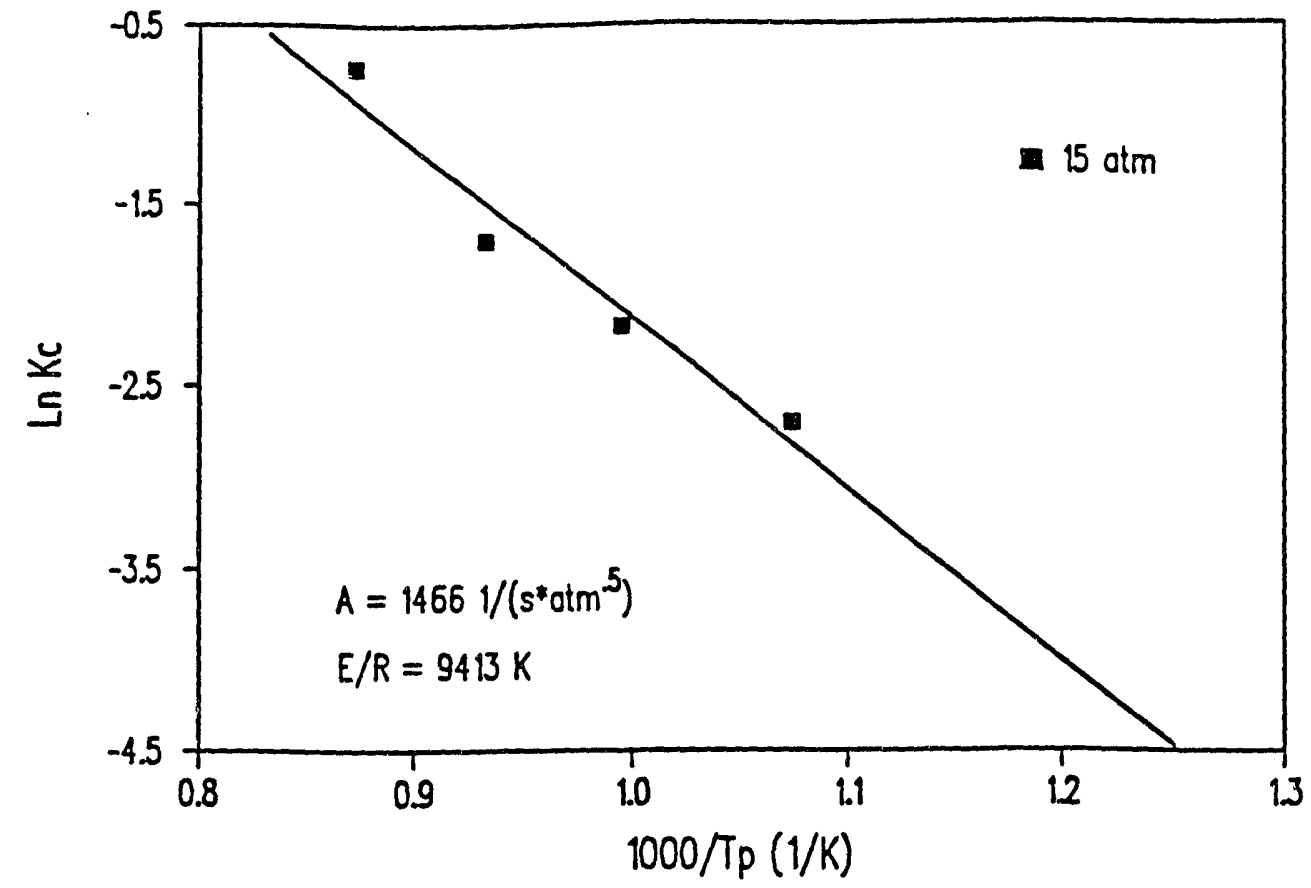

Fig. 2. Summaiy of the combustion rate measurements for UCC2 char. $\mathrm{Kc}$ is the combustion rate -de/dt corrected for external mass transfer and divided by $\mathrm{O}_{2}$ partial pressure in atm to the 0.5 power.

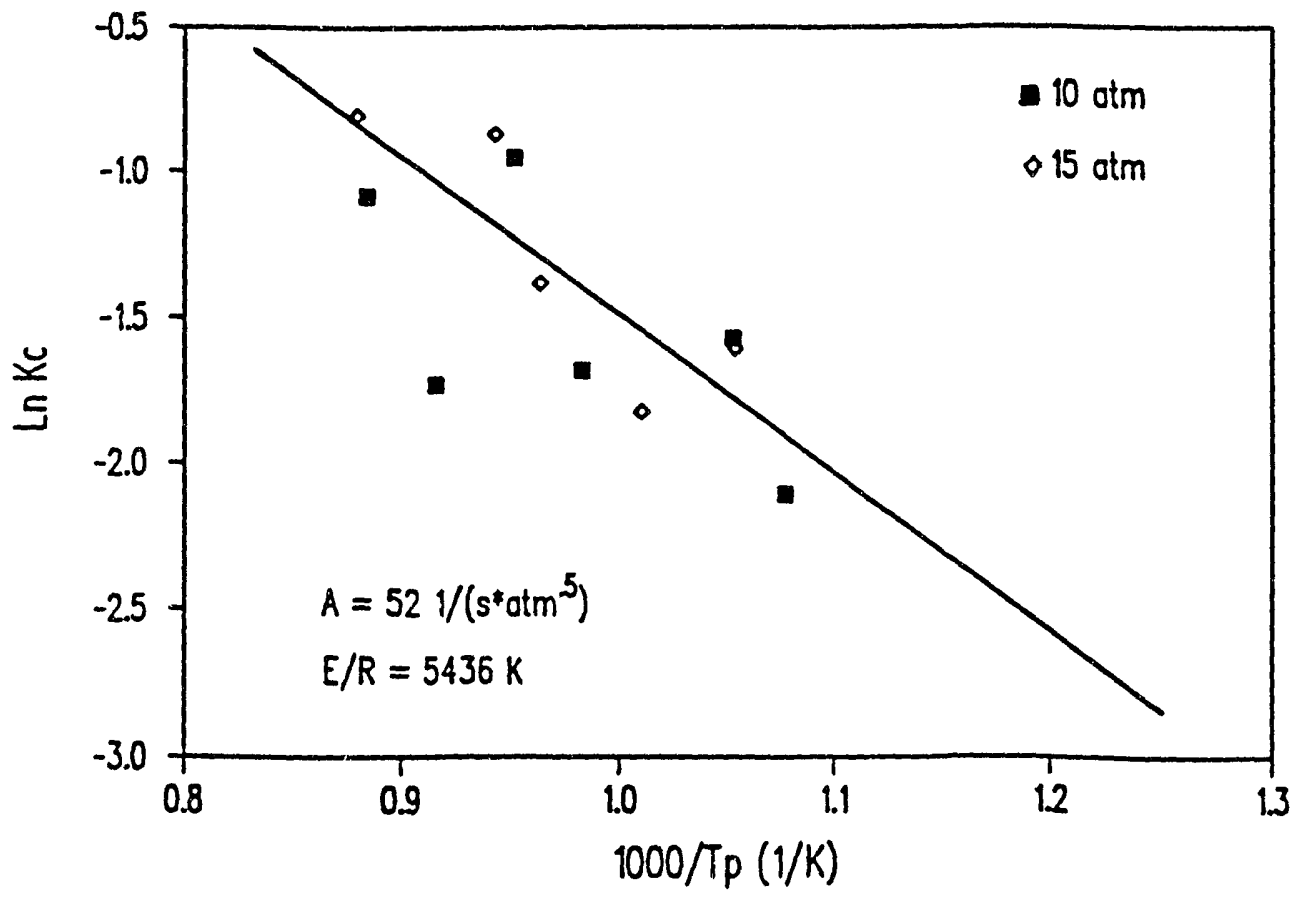

Fig. 3. Summary of the combustion rate measurements for IGTP1 char. Kc is the same as in Fig. 2. 


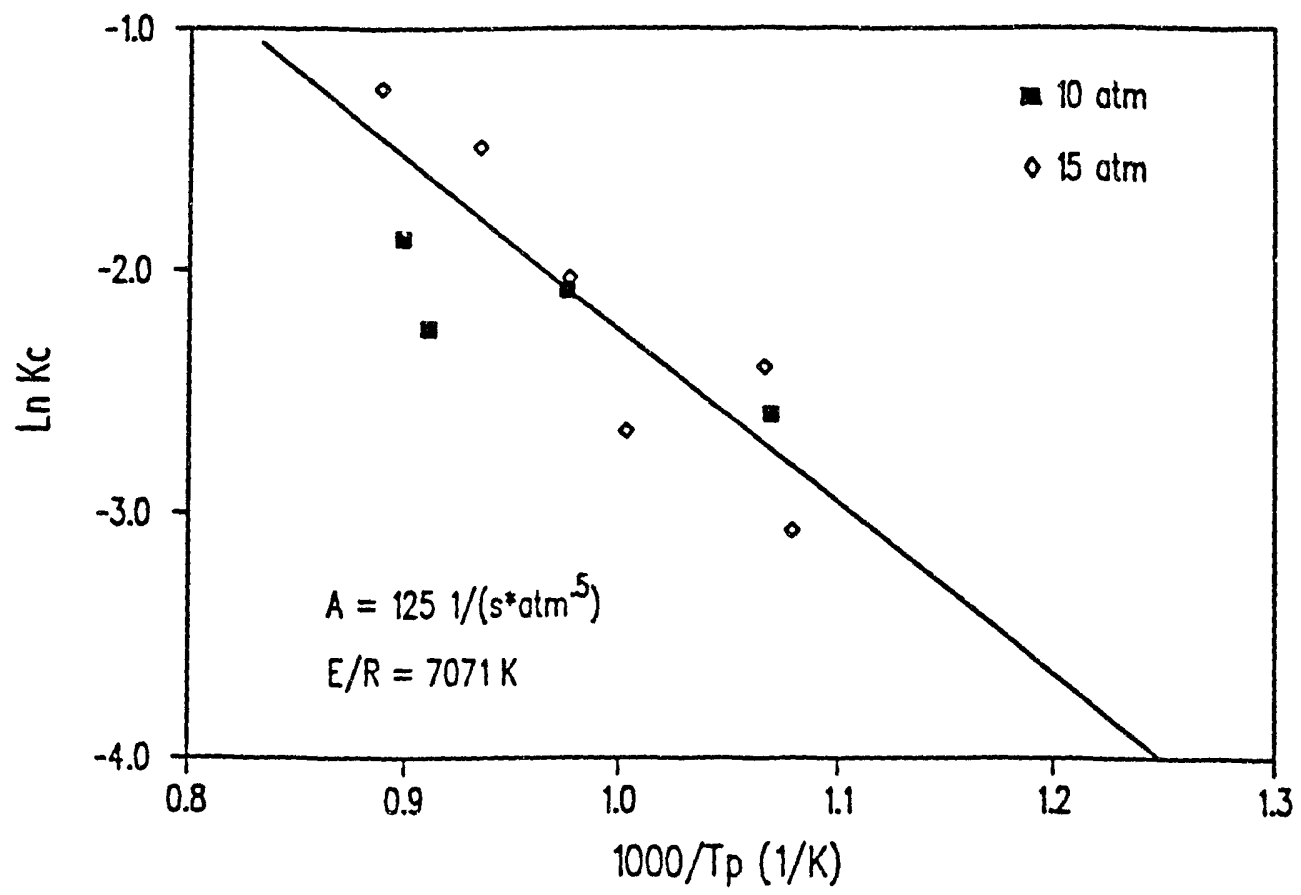

Fig. 4. Summary of the combustion rate measurements for IGTP2 char. Kc is the same as in Fig. 2.

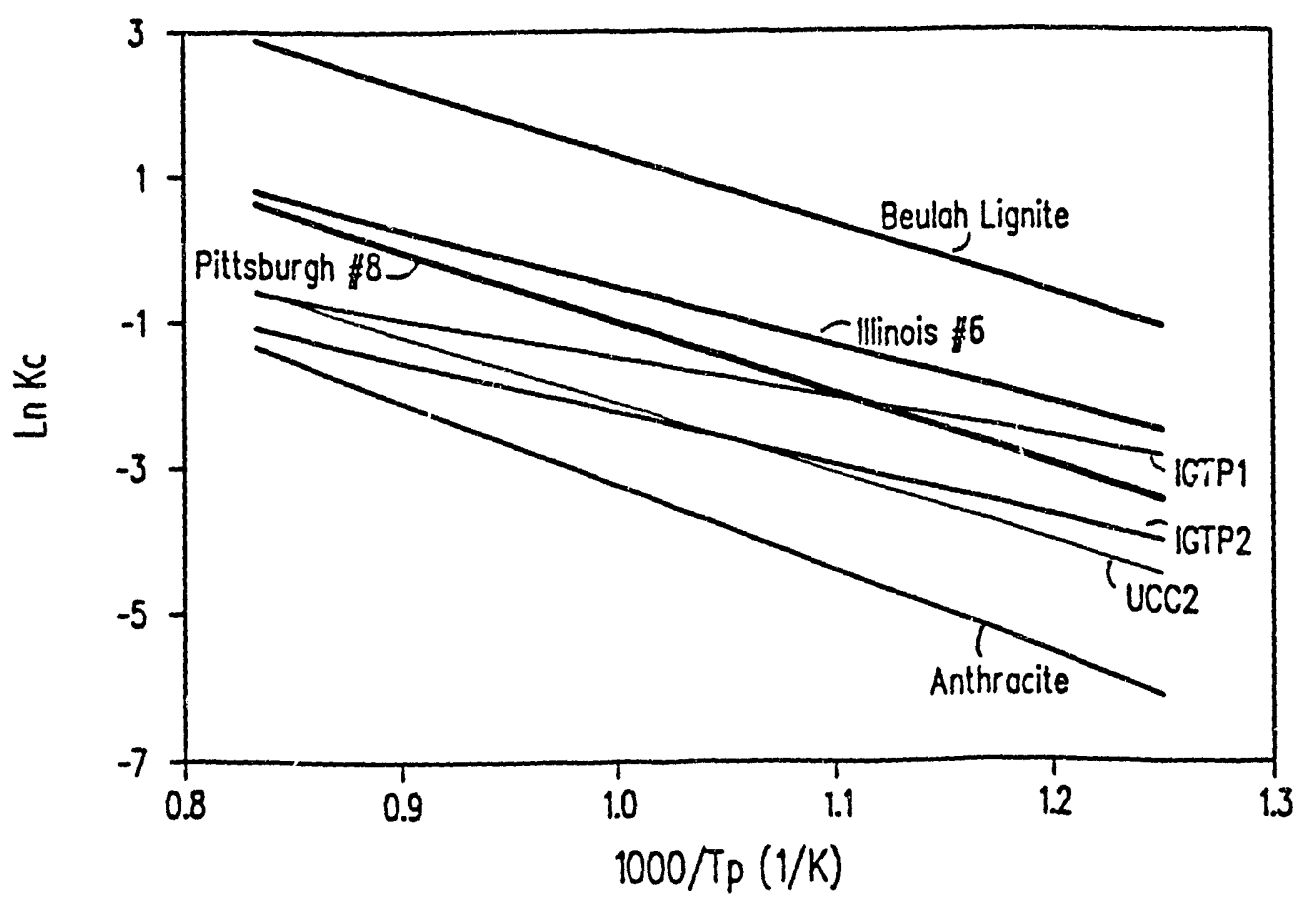

Fig. 5. Summary of the fitted burning rate equations for the three mild-gasification chars and the reference fuels. 


\section{PFBC MODEL DEVELOPMENT AND TESTING}

\section{Model Background}

In order to fully utilize the results of the bench-scale combustion tests, it was desirable to relate the inherent properties of the chars tested in this project to their expected performance in a utility-scale PFBC. This was accomplished by adapting an AFBC performance computer code developed earlier by Babcock and Wilcox (with assistance from ORNL) for the Electric Power Research Institute $(1,2)$.

The earlier B\&W/EPRI code had been developed in parallel with bench-scale tests for key AFBC fuel properties. The key fuel properties addressed in both the characterization procedures and the computer model were those associated with fuel particle degradation, volatiles release and combustion, heterogeneous carbon combustion, and particle transport through the combustion zone. Fuel particle degradation was recognized as resulting from a combination of feed-system attrition, fragmentation during particle heatup, and combustion-enhanced mechanical attrition. The basic scenario for coal particle combustion followed by the model for underbed feed is depicted in Fig. 6.

The AFBC code predicts combustion of both the volatile and fixed carbon fuel fractions, including the portions of each that burn in the bed and freeboard (i.e., the "heat split") and the overall combustion efficiency for each specific set of operating conditions and fuel. Freeboard temperatur: profile is also estimated. Both no-fly ash-recycle and fly ash-recycle operation can be simulated. Sulfur capture performance is not currently predicted by the model, but the code structure is designed to easily accommodate a sulfur capture component.

The in-bed portion of the $\mathrm{ArBC}$ code simulates the following elements of fuel behavior in order to estimate combustion performance: feed system attrition, fuel devolatilization, fuel swelling and fragmentation, coarse char attrition, coarse and fines char combustion in the bed, and fine char elutriation. Specific bench-scale characterization parameters correspond with each of these processes. The computations involved include detailed particle size population balances, local and global heat and mass transport, and horizontal gas-phase and fuel fines concentration gradients in the bed. The final estimate of in-bed combustion is based on the fraction of fixed carbon and volatiles that exit from the top of the bed and are carried into the freeboard.

The fieeboard portion of the AFBC code is primarily concerned with estimating the combustion of the volatiles and elutriated char fines leaving the bed. The computations involved are less detailed than those in the bed. Basically, the freeboard is treated as a vertical sequence of well-stirred reactors. Fines and volatiles combustion in each stage are estimated on the basis of their reactivities, local temperature, local oxygen concentration, local oxygen mass-transfer rates, and the appropriate residence time. 
Calculations in both the bed and freeboard are carried out on the basis of a "typical" unit cell. This cell is constructed to represent an "average" region above a feedpoint; thus the total number of unit cells is equal to the total number of feedpoints.

The AFBC model has been extensively validated against performance data from the $B \& W$ $1 \mathrm{ft}^{2}$ and Tennessee Valley Authority (TVA) $20 \mathrm{MW}(\mathrm{e})$ AFBC pilot facilities $(1,2)$. Predicted combustion efficiencies were compared with the measured performance of the $\mathrm{B} \& \mathrm{~W} 1 \mathrm{ft}^{2}$ unit operating under no-recycle conditions with 13 wide-ranging fuel types and with the TVA $20 \mathrm{MW}(\mathrm{e})$ unit operating under no-recycle conditions with two different fuels. In all cases, the in-bed combustion efficiency was predicted within $\pm 4 \%$ of the observed value, which varied between approximately 60 and $92 \%$. Freeboard and overall combustion efficiency predictions also closely matched the observations. The maximum error in the predicted overall combustion efficiency was within $2 \%$ over an observed combustion efficiency range of approximately 65 to $99 \%$.

\section{Modification of AFBC Performance Code for Pressure}

The specific version of the AFBC performance model from which the PFBC code is derived is designated by the program name FBCODEU. Pressure is an input to the modified PFBC code as one of the list of standard operating parameters. It is assumed that the input pressure corresponds to the average pressure at the bed surface.

Estimates of fluidization hydrodynamics, particle elutriation, and combustion are made using the average above-bed pressure specified in the input. The first two components are directly affected by pressure through gas density which varies with pressure according to the ideal gas law. The effect of pressure on viscosity is neglected in the model as it is known to be very small. The basic hydrodynamics calculations in the PFBC code are unchanged from the AFBC code since they were originally derived by $\mathrm{B} \& \mathrm{~W}$ to be generically applicable over a wide pressure range.

Combustion is affected by pressure primarily through the oxygen concentration which appears in intraparticle reaction kinetics rate expression. It was determined through the pressurized bench-scale fixed-bed experiments described previously that the basic combustion rate expressions used in the AFBC model are suitable for pressurized operation as long as oxygen concentration is properly accounted for. Combustion is also affected slightly by changes in the heat transfer from burning char particles in the bed. This again is primarily a function of gas density. Gas thermal conductivity and viscosity are kept constant with pressure. 


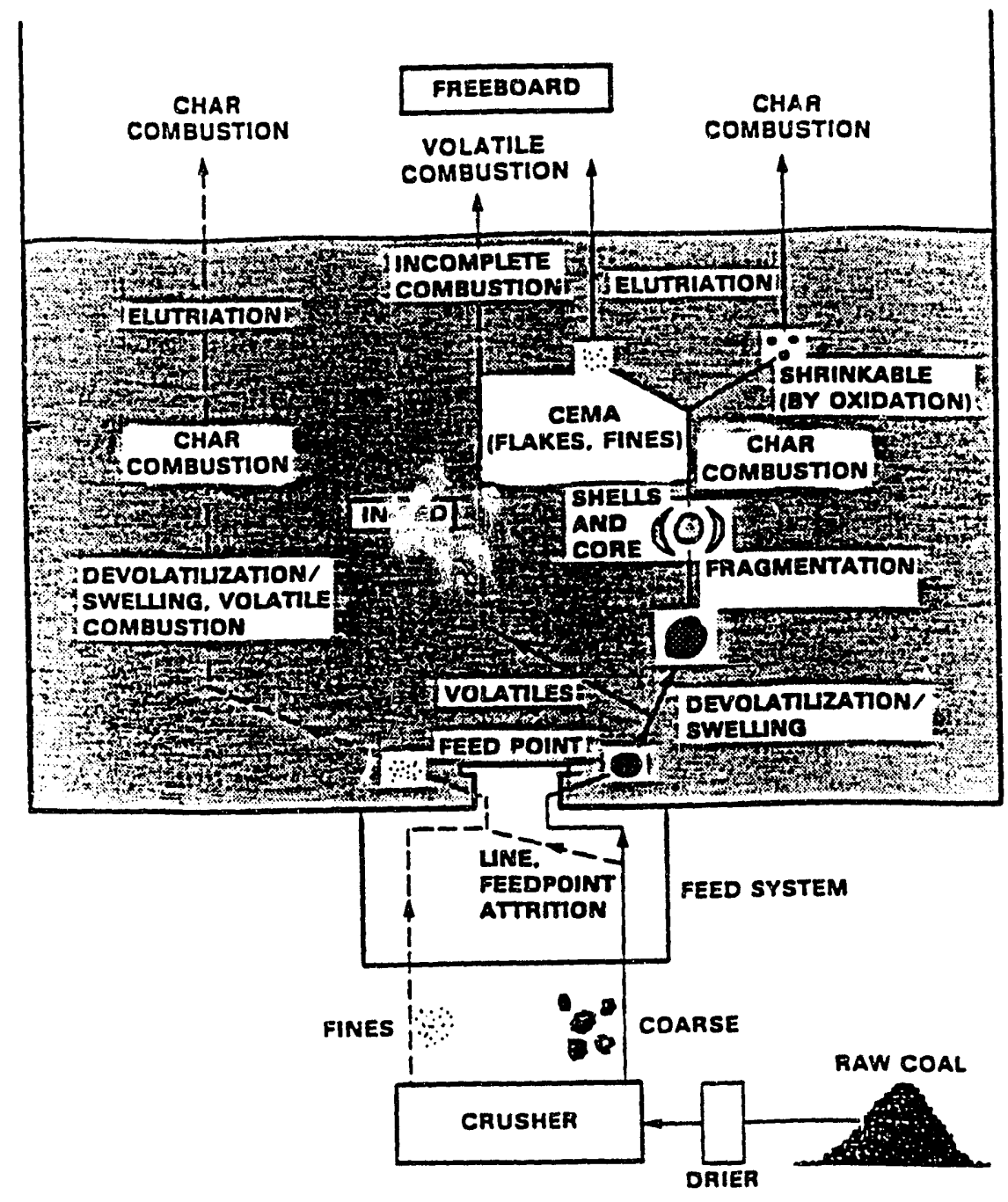

Fig. 6. Basic scenario assumed by the simulation model for coal combustion with uncierbed feed. 
The freeboard portion of the code was modified in the pressurized version to allow for a smaller minimum number of combustion zones or stages. It was determined that this reduced number of stages is more realistic for PFBCs. It was also determined that the large unit cell dimensions typical for PFBCs makes it more important to account for lateral mixing inefficiencies (i.e., reduced lateral oxygen transport) in the freeboard stages. An estimation procedure was included in the modified program to estimate the magnitude of these inefficiencies and to incorporate this effect into the burning rate predictions.

An important difference between typical AFBC and PFBC operation that has not yet been resolved centers on the use of slurry or "paste" fuel feed for PFBC. In the latter case, the fuel is pumped into the combustion chamber as a high-pressure water slurry instead of being pneumatically conveyed. The degree of fuel particle attrition occurring in paste feed systems is not well known, and it is uncertain that the attrition estimation procedure originally developed for the AFBC model is really appropriate for PFBC. This may not be a problem, however, since tuel samples can be collected from paste feeders very near the point of fuel injection. As an interim approach, we have adopted the original attrition algorithm in the PFBC model. When the particle size distribution in the paste is known, the attrition constant in the model is set very low to essentially eliminate further fuel particle size degradation prior to injection in the combustor.

An additional unknown factor associated with slurry feed is the effect of the water on the fuel heatup time and potential agglomeration of fuel particles. This issue has not been explored sufficiently at this time to allow development of an appropriate correlation for use in the performance model.

\section{PFBC Performance Code Sensitivity Analyses}

Previous evaluations of the AFBC performance model demonstrated that parametric model sensitivity studies are useful in revealing the most important fuel characterization issues and the uncertainties in performance estimates based on those characterizations (2). Similar sensitivity analyses were conducted with the modified PFBC version considering both operating variables and fuel parameters. Performance estimates were made for a utility PFBC boiler matching the nominal characteristics of the demonstration unit at the AEP Tidd plant. The objectives were to estimate the relative importance of the various fuel properties and to verify which of the fuel parameters should receive the greatest attention in bench-scale characterization tests of chars. Performance sensitivity was evaluated in terms of the relative effect of each fuel parameter on the in-bed combustion efficiency, the overall combustion efficiency, and the combustion heat split (ratio of in-bed to total efficiency).

Detailed results of the PFBC performance code sensitivity analyses are given in reference 9. Briefly, the most significant findings were:

- Large variations in the intrinsic fuel characteristics can be as important as large operating parameter changes (e.g., large changes in excess air). 
- Fuel property variations have more impact on freeboard combustion and combustion split than on in-bed combustion.

- Fuel combustion reactivity, swelling index, and friability in the feed system are the most important intrinsic fuel parameters affecting PFBC combustion performance. Of these, reactivity is probably the most important.

- Probably the next most important fuel property is feed system friability. This has not yet been evaluated for any mild-gasification chars and is complicated by the fact that many PFBC feed systems feed the fue ${ }^{1}$ as a water slurry.

- Swelling index is an important parameter for some coals, but is not significiat for the mild-gasification chars evaluated so far. Most of the swelling occurs in the mild-gasification reactor and thus is not a factor in the combustor.

\section{PFBC PERFORMANCE ESTIRTES FOR MILD-GASIFICATION CHARS}

\section{Simulation Model Operating Assumptions and Fuel Input Parameters}

Performance estimates for the UCC2, IGTP1, and IGTP2 chars were made for a typical utility PFBC boiler having nominal characteristics similar to those of the American Electric Power $75 \mathrm{MW}(\mathrm{e})$ Tidd PFBC demonstration facility. Table 2 summarizes the assumed boiler operating conditions input to the PFBC simulation code.

Input fuel parameters for the chars and reference fuels were determined from their standard ASTM analyses (Table 1) and the results of the bench-scale characterization tests at B\&W's Alliance Research Center. The required characterization information for the reference fuels was available from the $\mathrm{B} \& \mathrm{~W}$ data base, and the combustion reactivity information for the mild-gasification chars was generated in the pressurized bench-scale reactor as described earlier. Note that the combustion reactivity parameters for Beulah lignite are those previously measured at low-pressure conditions. It was necessary to use the previous values as the new parameters could not be accurately measured in the pressurized bench-scale facility.

Based on very limited measurements of particle size attrition in paste-type feed systems, it was assumed that all of the fuels (including the chars) would have a very small (essentially negligible) degree of attrition in the feed system. Char devolatilization parameters were assumed to be equal to those of anthracite because of the very low levels of volatiles present in UCC2, IGTP1, and IGTP2. Major fuel input parameters and higher heating values are summarized in Table 3. 


\section{Simulation Results}

The PFBC simulation performance results are summarized in Table 4. In this table, the three mild-gasifistion chars for which accurate combustion rate measurements could be made are compared with the reference fuels in terms of estimated combustion efficiency, both in the bis and orerall. The freeboard combustion performance can also be inferred from the estimated maximum freeboard temperature and the difference between the in-bed and overall efficiencies. The last column in the table is an estimate for overall combustion efficiency produced by the so-called Hoy correlation for PFBC (10).

In general, it appears that the more reactive fuels burn up more quickly in the bed, thus increasing in-bed combustion efficiency and decreasing freeboard combustion. Conversely, less reactive fuels leave more residual carbon fines that are entrained in to the freeboard where they burn and produce higher freeboard temperatures. Such delayed combustion and increased freeboard temperatures are usually undesirable. Anthracite is the least reactive fuel and has the poorest combustion performance, whereas Beulah lignite is the most reactive and best performing. Of the chars evaluated, the UCC 2 and IGTP1 are better than IGTP2. It would be expected that the more reactive SGI and WRIA chars would give better performance than UCC2 and IGTP1, probably similar to that of Beulah lignite.

Until more field data are available from Tidd for comparison with the model predictions, the results in Table 4 should clearly be considered tentative. Nevertheless, the results of recent field tests with Pittsburgh No. 8 at the Tidd facility in June of 1991 give support for optimism. These measurements produced estimates for in-bed and overall combustion efficiencies of $96 \pm 1 \%$ and $98 \pm 1 \%$, respectively, for similar operating conditions (9). This is quite close to the predicted values of $95.8 \%$ and $97.8 \%$ in Table 4 . It is also reasonable to expect that the relative ranking of the fuels will stay the same even if the accuracy of the absolute predictions is improved in the future.

Noie that the Hoy correlation does not differentiate between the various fuels at all and generally overpredicts the combustion performance. This illustrates the importance of more refined prediction methods such as FBCODEU. 
Table 2. PFBC operating conditions assumed for performance simulations

Expanded bed height: 132 in. $(3.35 \mathrm{~m})$

Freeboard height: 168 in. $(4.27 \mathrm{~m})$

Average bed temperature: $1550^{\circ} \mathrm{F}(1117 \mathrm{~K})$

Freeboard pressure: $12 \mathrm{~atm}\left(1.22 \times 10^{6} \mathrm{~Pa}\right)$

Total air flow: $122,000 \mathrm{lb} / \mathrm{h}(55,400 \mathrm{~kg} / \mathrm{h})$

Excess air (above stoichiometric): $25 \%$

Splitting air (at feed injectors): $1 \%$ of total air

Number of active feedpoints: 6

Area per feed point: $56 \mathrm{ft}^{2}\left(5.2 \mathrm{~m}^{2}\right)$

Fines recycle: None.

Sauter mean bed particle size: 833 microns

Average bed particle density: $2.6 \mathrm{~g} / \mathrm{cm}^{3}$

Fuel condition: Water paste with following particle distribution

\begin{tabular}{cc}
$\frac{\text { Size(microns) }}{3}$ & Cum \% less than \\
\cline { 1 - 2 } & 15.3 \\
125 & 25.1 \\
250 & 34.9 \\
500 & 42.8 \\
1000 & 55.4 \\
2000 & 74.9 \\
3000 & 85.8 \\
4000 & 94.0 \\
6350 & 100.0
\end{tabular}

-Fuel flow adjusted to give specified excess air at specified total air flow. 
Table 3. Major fuel characterization parameters used for performance simulations

\begin{tabular}{||c|r|r|r|r|c|c||}
\hline Fuel & $\begin{array}{c}\text { HHV } \\
\text { (Btu/lb) }\end{array}$ & $\begin{array}{c}\text { Comb. } \\
\text { Preexp. } \\
\text { fac. (1/s) }\end{array}$ & $\begin{array}{c}\text { Reactivity } \\
\text { Act. } \\
\text { temp.(K) }\end{array}$ & $\begin{array}{c}\text { Devol. } \\
\text { type }^{3}\end{array}$ & $\begin{array}{c}\text { Feed } \\
\text { attrit. }^{4}\end{array}$ & $\begin{array}{c}\text { Swell } \\
\text { index }^{5}\end{array}$ \\
\hline Chars: & & & & & & \\
UCC2 & 10768 & 1466 & 9413 & Ant. & Low & 1.0 \\
IGTP1 & 8747 & 52 & 5436 & Ant. & Low & 1.0 \\
IGTP2 & 9830 & 125 & 7071 & Ant. & Low & 1.0 \\
\hline Ref.: & & & & & & \\
BH.LIG. & 6832 & $47442^{6}$ & $9463^{6}$ & Lig. & Low & 1.0 \\
PITT. 8 & 978 . & 6772 & 9815 & HVB & Low & 1.71 \\
ILL.6 & 8582 & 1684 & 7947 & HVB & Low & 1.34 \\
ANTHR. & 9821 & 3829 & 11492 & Ant. & Low & 1.0 \\
\hline
\end{tabular}

${ }^{1}$ Heating value of paste as fed to boiler.

${ }^{2}$ Activation energy divided by the ideal gas constant.

${ }^{3}$ General type of devolatilization behavior: Ant. = like anthracite; Lig. = like lignite; $\mathrm{HVB}=$ like high-volatile bituminous coal.

${ }^{4}$ Low means effectively no attrition.

${ }^{5}$ Ratio of pre- to post-sv $1: \mathrm{gg}$ particle diameter.

${ }^{6}$ Determined from low-presius a bench-scale measurements.

Table 4. Summary of simulated PFBC performance for three mild-gasification chars and the reference fuels

\begin{tabular}{||c|c|c|c|c||}
\hline Fuel & $\begin{array}{c}\text { Max. freeboard } \\
\left.\text { temperature ( }{ }^{\circ} \mathrm{F}\right)\end{array}$ & $\begin{array}{c}\text { In-bed } \\
\text { CE (\%) }\end{array}$ & $\begin{array}{c}\text { Overall } \\
\text { CE (\%) }\end{array}$ & $\begin{array}{c}\text { Hoy corr. } \\
\text { CE (\%) }\end{array}$ \\
\hline Chars: & & & & \\
UCC2 & 1579 & 0.942 & 0.965 & 0.994 \\
IGTP1 & 1579 & 0.946 & 0.967 & 0.994 \\
IGTP2 & 1583 & 0.929 & 0.957 & 0.994 \\
\hline Ref.: & & & & \\
BH.LIGN. & 1563 & 0.978 & 0.989 & 0.994 \\
PITT. 8 & 1570 & 0.958 & 0.978 & 0.994 \\
ILL.6 & 1574 & 0.951 & 0.975 & 0.994 \\
ANTHR. & 1587 & 0.917 & 0.946 & 0.994 \\
\hline
\end{tabular}

${ }^{1}$ Combustion efficiency (CE) is defined in terms of the percent of the inlet fuel heating value released. 


\section{CONCLUSIONS AND RECOMMENDATIONS}

Based on the bench-scale characterization tests and PFBC performance simulations conducted under this CRADA, it is concluded that:

- Pressurized combustion parameters were accurately determined for three chars, UCC2, IGTP1, and IGTP2.

- Pressurized combustion parameters could not be accurately determined for the WRIA and SGI chars because of their high burning rates and the insufficient time resolution of the pressurized fixed-bed reactor.

- For the first three chars, their estimated PFBC performance ranking (in terms of overall and in-bed combustion efficiency) is IGTP1 > UCC2 > IGTP2. The best of these, IGTP1, still ranks below Pittsburgh No. 8 and Illinois No. 6 coals.

- Although the pressurizeo combustion parameters of the SGI and WRIA chars could not be accurately determined, their fast-burning characteristics indicate that their PFBC performance will be better than the UCC and IGTP chars and similar to that of Beulah lignite.

It is recommended that future studies to estimate PFBC performance of mild-gasification chars should include the following:

- Improved measurement of the pressurized combustion rate parameters for fast-burning fuels.

- Improved procedures for estimating attrition and drying of paste-type fuel feed in PFBCs.

- More direct comparisons of FBCODEU predictions for reference fuels with field PFBC data.

\section{References}

1. C. S. Daw, D. R. Rowley, M. A. Perna, J. W. Stallings, and R. J. Divilio, "Characterization of Fuels for Atmospheric Fluidized Bed Combustion," Proceedings of the Eleventh International Conference on Fluidized Bed Combustion, Montreal, American Society of Mechanical Engineers, vol. 1, pp 157-166, May 1991.

2. M. A. Perna, D. R. Rowley, D. D. Sutherland, C. S. Daw, and R. J. Divilio, "Characterizing Fuels for Utility-Scale Atmospheric Fluidized Bed Combustors," Electric Power Research Institute Report No. EPRI GS-7208, May 1991. 
3. R. L. Graves, C. S. Daw, R. P. Krishnan, B. H. West, A. L. Compere, and W. L. Griffith, "Mild-Gasification Product Characterization," Proceedings of the Eleventh Annual Gasification and Gas Stream Cleanup Systems Contractors Review Meeting," DOE/METC-91/6123, vol. 1, pp 124-132, August 1991.

4. C. S. Daw and M. A. Perna, "Combustion Reactivity of Mild-Gasification Chars," Eighth Annual International Pittsburgh Coal Conference, Pittsburgh, pp 84-93, September, 1990.

5. United Coal Company, Project Status Report, UCC R\&D C17-20, Contract No. DE-AC21-87MC23289, September 16, 1988.

6. E. P. Erstergar, SGI International, La Jolla, California, October 1988.

7. M. Onischak, J. Gissy, R. A. Knight, S. P. Babu, J. M. Wooten, R. G. Duthie, and J. R. Longanbach, "Development of the IGT Mild Gasification Process in a 100-Pound-Per-Hour Process Research Unit," Intersociety of Energy Conversion Engineering Conference, Reno, Nevada, August 1990.

8. S. Y. Shiao and J. J. Warchol, "Studies on Coal Devolatilization and Char Reactivity Under PFBC Conditions," DOE/MC/23247-2985 (DE 91002065), December 1990.

9. S. Y. Shiao, M. A. Perna, D. D. Sutherland, D. R. Rowley, and C. S. Daw, "Characterization of Ohio and Illinois Coals Under PFBC Conditions," Babcock and Wilcox, report to ASEA Babcock and the Ohio Coal Development Office, RDD:93:41790-007-01:01, August 1992.

10. H. R. Hoy, A. G. Roberts, J. E. Statan, and D. M. Wilkins, "Pressurized Fluidized-Bed Combustion: Supplement to Report on Work Carried Out at the Coal Utilization Research Laboratories, "Leatherhead, England, DOE/MC/22190-2356(DE 87006485), p. 95, 1986. 

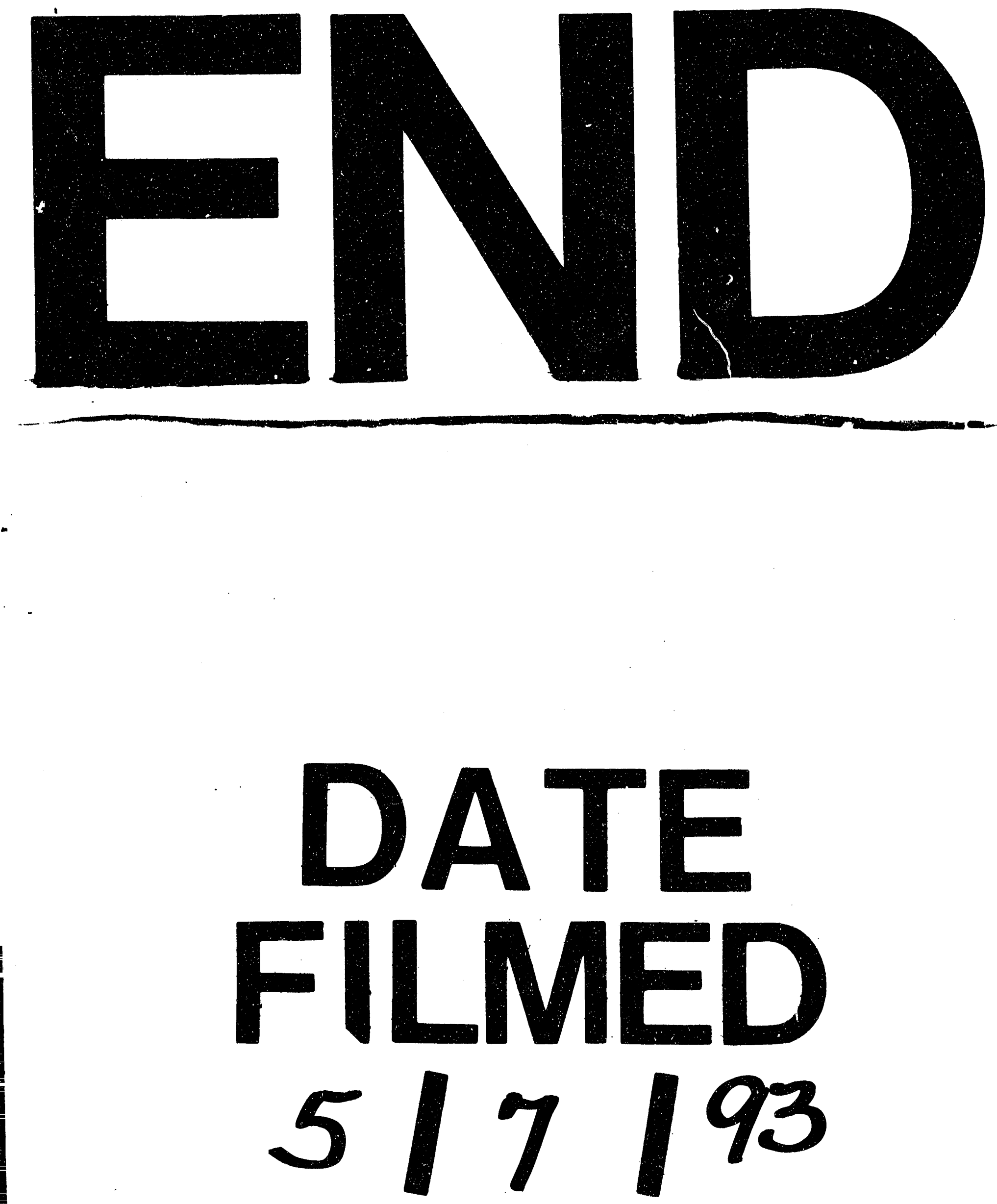
